\title{
AN EVALUATION OF FOAMING POTENTIAL IN THE IDMS MELTER (U)
}

by N. D. Hutson

WSRC-TR--92-491

Westinghouse Savannah River Company

DE93 006246

Savannah River Site

Aiken, South Carolina 29808

Other Authors:

\section{DISCLAIMER}

\begin{abstract}
This report was prepared as an account of work sponsored by an agency of the United States Government. Neither the United States Government nor any agency thereof, nor any of their employees, makes any warranty, express or implied, or assumes any legal liability or responsibility for the accuracy, completeness, or usefulness of any information, apparatus, product, or process disclosed, or represents that its use would not infringe privately owned rights. Reference herein to any specific commercial product, process, or service by trade name, trademark, manufacturer, or otherwise does not necessarily constitute or imply its endorsement, recommendation, or favoring by the United States Government or any agency thereof. The views and opinions of authors expressed herein do not necessarily state or reflect those of the United States Government or any agency thereof.
\end{abstract}

This paper was prepared in connection with work done under Contract No. DE-AC09-89SR18035 with the U.S. Department of Energy. By acceptance of this paper, the publisher and/or recipient acknowledges the U.S. Government's right to retain a nonexclusive, royalty-free license in and to any copyright covering this paper, along with the right to reproduce and to authorize others to reproduce all or part of the copyrighted paper.

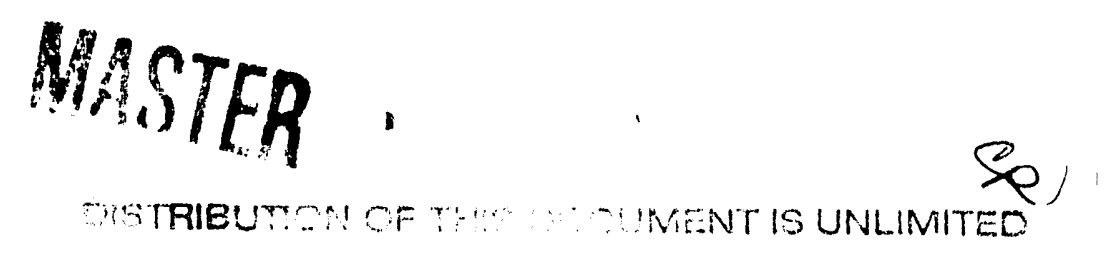




\author{
Keywords: DWPF, IDMS, Mercury, \\ Nitric Acid Flowsheet, \\ Late Wash, Melter, \\ Melter Foaming \\ Retention: Permanent \\ CC: L. M. Papouchado, 773-A \\ L. F. Landon, 704-T \\ C. T. Randal1, 704-T \\ J. T. Carter, 704-1T \\ M. J. Plodinec, 773-A \\ D. F. Bickford, 773-A \\ D. H. Miller, 704-1T \\ M. E. Smith, 704-1T \\ SRTC Records (4)
}

October 22,1992

TO: E. W. Holtzscheiter, 773-A

FROM: N. D. Hutson, 704-1T

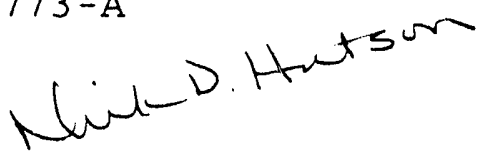

\title{
An Evaluation of Foaming Potential In the IDMS Melter $(0)$
}

\section{Introduction and Summary}

The present DWPF flowsheet calls for the chemical treatment of waste sludge with 90 wt formic acid prior to the addition of the Precipitate Hydrolysis Aqueous (PHA) product. An alternative processing methodology, denoted the "Nitric Acid Flowsheet", has been proposed. In the application of this flowsheet, nitric acid would be used to neutralize sludge tase components (hydroxides and carbonates) prior to the addition of late wash PHA. The late wash PHA will contain sufficient quantities of formic acid to adequately complete necessary reduction-oxidation (REDOX) reactions.

The use of this flowsheet may result in a change in the nominal concentrations of two of the major REDOx reaction participants: formate $\left(\mathrm{HCOO}^{-}\right)$and nitrate $\left(\mathrm{NO}_{3}{ }^{-}\right)$.

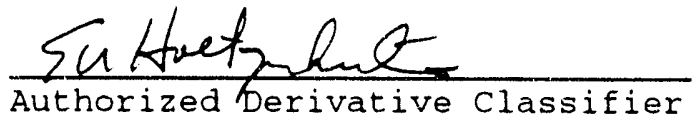


An imbalance in REDOX agents in the melter can result in overly reducing melts which favor the formation and accumulation of metals and metallic sulfides (including selenides and tellurides). Conversely, if the REDOX potential of the melt is imbalanced to the point of being overly oxidizing, there may be an increased amount of volatilized ${ }^{106} \mathrm{Ru}$. Overly oxidized melts can also result in excessive melter foaming.

Uncontrolled glass foaming can result in blockage of critical melter or melter offgas components. 1 An insulative layer of foam on the melt surface can also retard heat transfer to the liquid slurry and will increase the temperature of the melt below. A typical response to a foaming is to stop slurry feeding, allow the foam to dissipate, allow the melter temperatures to return to normal, and slowly resume operation. ${ }^{2}$

The IDMS has processed 4 batches of melter feed using the Nitric Acid Flowsheet. For the first two of these runs, HANtype PHA was used in the make-up of the melter feed. These melter feeds had very high nitrate-to-formate molar ratios $(\mathrm{N} / \mathrm{F})$. During the processing of the HM4 melter feed, with a $\mathrm{N} / \mathrm{F} \approx 16$, there was an uncontrolled pour of glass which may have been a result of foaming in the melter. Due to the severity of this event the nitric acid flowsheet is not recommended when paired with HAN-type PHA. However, there no evidence to suggest that melter foaming will be a problem when pairing the nitric acid flowsheet with the Late wash PHA.

\section{Background}

In tests conducted by Goldman, et.al, 2 at Battelle Pacific Northwest Laboratory, it was found that glasses exhibiting the most tendency for foaming were those which were highly oxidized (contained no ferrous ion) and were made from slurries containing nitrate chemicals and lacking any reducing agent. Numerous tests have shown that foaming is diminished when reducing agents are included in the feed slurry, either in the processed waste (organics, oxalates) or as separate additives (formic acid, sugar). A reduced glass contains less dissolved oxygen and should therefore have a lower foaming tendency. However, even under highly reducing conditions, there is ample supply of oxygen available to produce a substantial foam layer. Goldman showed that foams generated under reducing conditions were unstable. He proposed that, under reducing conditions, proportionally more water vapor is released which destabilizes the foam.

Bickford ${ }^{1}$ and $\mathrm{Hrma}^{3}$ have reported that, in typical defense waste glass, $\mathrm{MnO}_{2}$ will release oxygen as it dissolves in the glass as $\mathrm{Mn}$ (II) and suggest that it is the major contributor to melter foaming. $\mathrm{Hrma}^{3}$ indicated that foaming will not be 
extensive if $\approx 66 \%$ (the $\mathrm{Mn}$ is reduced to $\mathrm{Mn}$ (II) prior to vitrification. In a highly oxidizing melt (high nitrates relative to reducing agents) however, it is proposed that Mri(II) can be re-oxidized at relatively low temperatures before being re-reduced at higher temperatures when the MnO becomes dissolved in the glass.

\section{IDMS Experience - Formic Acid Flowsheet}

The Integrated DWPF Melter system (IDMS) is a pilot scale melter system which has been in operation since the Fall of 1988. To date the facility has conducted 16 runs using the current (formic acid) flowsheet and 2 runs in support of the Hanford vitrification (using formic acid). In each case, formic acid was added in order to, among other things, reduce approximately $50 \%$ of the $\mathrm{MnO}_{2}$ to $\mathrm{Mn}$ (II).

There was no evidence to suggest that the IDMS melter ever experienced any significant foaming during the vitrification of the 16 runs using formic acid. There was also no evidence of foaming during the vitrification of the Hanford NCAW melter feeds, even though they contained the largest nitrateto-formate ratio (N:F) which had been processed in the facility to that date.

\section{IDMS Experience - Nitric Acid Flowsheet}

The IDMS has processed 4 batches of melter feed using the Nitric Acid Flowsheet (HM4, PX3, PX4, and PX5). A brief description of each run is shown in Table 1.

\section{Table 1. Summary of IDMS Nitric Acid Flowsheet Runs}

\begin{tabular}{|c|c|c|c|c|c|}
\hline Run ID & $\begin{array}{l}\text { Sludge } \\
\text { Type }\end{array}$ & $\begin{array}{l}\text { PHA } \\
\text { Type }\end{array}$ & $\begin{array}{c}\text { MF' } F \\
\text { (Molar) }\end{array}$ & $\begin{array}{c}\text { MFT N } \\
\text { (Molar) }\end{array}$ & $N / E$ \\
\hline HM4 * & HM-type & HAN & 0.099 & 0.807 & 8.0 \\
\hline $\mathrm{HM} 4$ * * & HM-type & HAN & 0.067 & 1.085 & 16.2 \\
\hline $\mathrm{PX} 3$ & PUREX & HAN & 0.135 & 0.824 & 6.0 \\
\hline PX 4 & PUREX & Late Wash & 0.368 & 0.410 & 1.1 \\
\hline PX5 & PUREX & Late Wash & $\mathrm{NA}$ & NA & $\mathrm{NA}$ \\
\hline HWVP1 & NCAW & none & 0.333 & 0.484 & 1.5 \\
\hline Nominal - & Various & HAN & - & - & $<1.0$ \\
\hline
\end{tabular}

* HM4 MFT after Transfer\#1 (mixed with previous heel)

* * HM4 on $6 / 9 / 92$

- General using formic acid flowsheet

$\mathrm{NA}=$ Not Available 
As seen in Table 1, the first two runs using the nitric acid flowsheet also used HAN-type PHA. The HAN-type PHA contains considerable quantities of nitrates and, when combined with the nitric acid flowsheet, produces a melter feed which is very high in nitrates relative to the formates present.

There was one time during the processing of the IDMS HM4 melter feed slurry when there may have been a foaming incident. The indicent took place on June 10, 1992 and the events are as follows:

$$
\begin{aligned}
& \text { July } 10,1992 \\
& \text { 01:35 - 08:20 Continuous slurry feeding } \\
& \text { 08:00 Melter level at } 111 \% \text { (overflow }=>122 \% \text { ) } \\
& \text { 08:20 Stopped feeding to backflush ultrafilter } \\
& \text { and change bagfilter (melt level = 114\%) } \\
& \text { 08:20 - 10:00 Melter level slowly increases from 114\% } \\
& \text { to } 121 \% \text { without feeding. } \\
& \text { 10:00 Start of uncontrolled pour, initially } \\
& \text { bellows was down. Bellows was raised } \\
& \text { and pour continued, indicating overflow. } \\
& 11: 22 \quad \text { Started controlled pour; melt level } \\
& \text { decreased from } 120 \% \text { to } 118 \% \text {. } \\
& \text { 13:15 - 13:30 Poured continuously at -2" pour spout } \\
& \text {-to-melter } \Delta \mathrm{P} \text {. }
\end{aligned}
$$

It is not clear that the overflow seen at 10:00 was a result of a foaming event in the melter but it is a possibility. There may have been a foam layer above the melt which was supported by the melter walls and would not have been measured by the melter level probe (a bubbler). Over time (from 08:20 to 10:00) the foam was melted and caused the melt level to increase and to eventually overflow. However, the melter foam detector (about 12" above the melt overflow level) never indicated that foam had been measured and the melter temperatures did not change as would have been expected by hindered heat transfer due to the foam.

At the time of this event, the nitrate-to-formate molar ratio in the melter feed slurry was 16 (see Table 1). This is by far the highest $\mathrm{N} / \mathrm{F}$ ever processed in the IDMS facility. 


\section{Conclusions}

The IDMS has processed 4 batches of melter feed using the Nitric Acid Flowsheet. For the first two of these runs, HANtype PHA was used in the make-up of the melter feed. These melter feeds had very high nitrate-to-formate molar ratios $(\mathrm{N} / \mathrm{F})$. During the processing of the HM4 melter feed, with a $\mathrm{N} / \mathrm{F}=16$, there was an uncontrolled pour of glass which may have been a result of foaming in the melter. Due to the severity of this event the nitric acid flowsheet is not recommended when paired with HAN-type PHA. However, there no evidence to suggest that melter foaming will be a problem when pairing the nitric acid flowsheet with the Late wash PHA.

\section{References}

1. D.F. Bickford, R.B. Diemer, and D.C. Iverson, "Redox Control of Electric Melters with Complex Feed Compositions II. Preliminary Limits for Radioactive Waste Melters", Journal of Non-Crystalline Solids, 84 (1986) 285-291.

2. D. S. Goldman, "Melt Foaming, Foam Stability and REDox in Nuclear Waste Vitrification", Journal of Non-Crystalline Solids, 84 (1986) 292-298.

3. P. Hrma, Case-Western Reserve University Contract Report, USDOE Report DPST-85-419, Savannah River Laboratory, Aiken, SC 29808 (1985). 

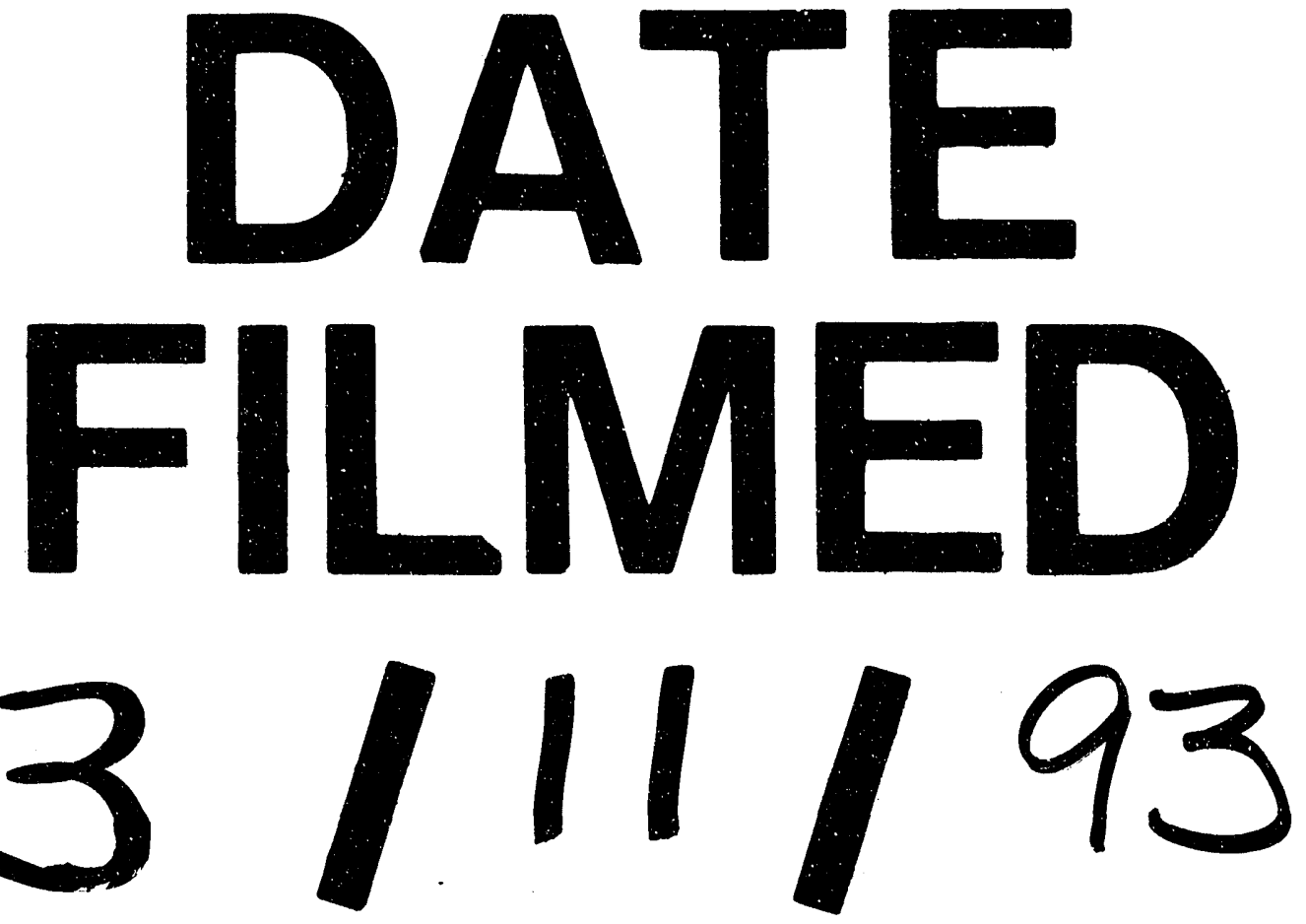